\title{
Teaching Writing in the Disciplines: Student Perspectives on Learning Genre
}

\section{ABSTRACT}

Writing in the Disciplines curricula can both challenge and reinforce assumptions that writing is a general skill that students will already have learned prior to doing the specialized writing in their chosen field of study. Rhetorical genre studies, however, tends to emphasize the situated nature of writing expertise, and thus supports the exploration of more sustained and varied forms of writing instruction in higher education. This article reports on a qualitative study that gave priority to a rich source of pedagogical insight: student writers themselves. In-depth interviews and surveys were used to examine the pedagogical practices and curricular experiences identified by students as being most helpful in developing undergraduate expertise in their discipline's research genre. These student-centered descriptions of successful genre learning point the way toward curricular and instructional models that emphasize the intellectual, affective, and relational nature of writing.

\section{KEYWORDS}

genre, writing in the disciplines, academic literacy, psychology, computer science

\section{INTRODUCTION}

Although it is a commonplace in writing research that written communication is a social competency as much as it is a cognitive skill, many faculty members continue to ask why their students haven't "learned to write" prior to entering their classes. They see neither their courses nor disciplines as places where students might do that learning. As the blame is passed down the line, underlying assumptions about language and writing remain unnoticed and uninterrogated: that academic writing is always situated, and that it is not merely a tool but a complex social action central to how a disciplinary community produces knowledge (Kaufer and Young, 1993; Russell, 2002; Bazerman et al, 2005; Carter, 2007; Elton, 2010). To the extent that these concepts don't inform the curricular and pedagogical decisions in higher education, our students don't experience "writing" as a form of engaged participation. ${ }^{1}$

Yet, as scholarship in rhetorical genre studies has made clear (Miller, 1984; Cooper, 1989; Hunt, 1994; Russell, 1995; Prior, 1998; Artemeva, 2008; Bazerman, 2009b; Bawarshi and Reiff, 2010), writing is best learned when there is intention: 
what is necessary is an occasion and a need to mean: some kind of rhetorical exigency which will elicit performance. Current theoretical reconceptualizations of genre as [a] recurring response to a rhetorical context highlight precisely these dimensions of social motive, rhetorical responsiveness and context. (Freedman, 1994, p. 201)

Genre mastery, therefore, can be seen not only as a primary measure of student writing proficiency - "the writer loses control of the writing when he or she does not understand the genre" (Bazerman, 2009a, p. 504) — but also as an important pedagogical vehicle. As Beaufort and Williams have argued, "genre theory forces us to ask ourselves if we aren't creating artificial barriers in our minds when we say, in subject areas outside writing and rhetoric, that we don't or can't teach writing" (2005, p. 63). Our students' writing reflects the degree to which they are capable of "doing the analytical work of the discipline," and thus teaching a discipline's genre is teaching the discipline (p. 64). Indeed, most Writing in the Disciplines (WID) programs foreground genre in ways that first-year writing curricula cannot. $^{2}$

Beginning in 2005, I had the opportunity to help implement a WID curriculum, providing support for departments as they identified and redesigned their designated writing intensive (WI) courses. Two majors in particular, psychology and computer science, developed second-year (sophomore) courses that focused on early exposure to the scientific research article as intentional preparation for fourth-year (senior) research writing in the capstone course. These departments provided an opportunity to examine how students move from seeing genre merely as a template to seeing it as a complex rhetorical construct for participating in their field.

I conducted in-depth, text-based, qualitative interviews with two groups of students: seniors whose records indicate that they had mastered their discipline's primary research genre, and sophomores who were in the early stages of learning those genres. Grounded theory, a qualitative methodology in which the coding is derived inductively from the data through a constant comparative data collection and analysis process, was used to better understand students' tacit knowledge of their own literate activity (Bryant and Charmaz 2010). The interviews were supplemented by surveys with sophomore and senior cohorts in each major. My study extends the work of Thaiss and Zawacki's influential Engaged Writers and Dynamic Disciplines: Research on the Academic Writing Life (2006) which set out to clarify the elusive nature of "academic writing" across the range of disciplines in the academy by asking those who are best informed and most directly involved: their own colleagues and students. As a systematic analysis of students' experience learning genre, my study is also a form of inquiry within the Scholarship of Teaching and Learning that seeks to examine the constituent features of an experience, or what Hutchings calls a "What is" type of question, offering a thick description of what learning genre looks like (Hutchings, 2000, p. 4).

In selecting participants, I used the framework provided by Thaiss and Zawacki's three stages of undergraduate disciplinary writing development. In this model, stage one writers assume there is a universal set of rules for college-level writing, and they try to understand these expectations based on a limited number of courses. Stage two writers, having experienced a far more diverse set of courses, adopt a "radically relativistic view" 
Table 1: Sequenced Writing Intensive Courses in Psychology and Computer Science

REQUIRED WRITING

\begin{tabular}{lll} 
INTENSIVE COURSES & PSYCHOLOGY & COMPUTER SCIENCE \\
\hline First-Year Seminar & Any discipline & Any discipline \\
\hline Pre-requisites & $\begin{array}{l}\text { Methods and Tools } \\
\text { Design and Statistical Analysis }\end{array}$ & $\begin{array}{l}\text { Computational Problem-Solving } \\
\text { Data Structures and Algorithms }\end{array}$ \\
\hline $\begin{array}{l}\text { Mid-level WI course in the } \\
\text { major }\end{array}$ & Research Seminar & Programming in the Large \\
\hline $\begin{array}{l}\text { Senior-level WI capstone course } \\
\text { in the major }\end{array}$ & $\begin{array}{l}\text { Internship, Special Topics, or } \\
\text { Independent Research/Thesis }\end{array}$ & Internships or Mentored Research \\
\hline
\end{tabular}

(p. 139) in which differing expectations are seen merely as the idiosyncrasies of faculty members and not as differences that align with disciplinary standards. Stage three writers, however, have moved toward "building a complex but organic sense of the structure of the discipline," are able to perceive "coherence-within-diversity," and, most importantly, achieve a sense of their own "place within the disciplinary enterprise" (p. 139).

I purposely chose to work with seniors who had, in fact, arrived at stage three, and I intentionally selected departments whose faculty members view their courses as places of "learning to write." 3 Specifically, I wanted to expand the portion of Thaiss and Zawacki's study that looked at what students "say about how they learn to write in their disciplines" (p. 96). While Thaiss and Zawacki used student surveys, focus groups, and proficiency exams, a more situated study of these writers using in-depth interviews has much to teach us about how we can best facilitate students' writing expertise. In what follows I review my study's institutional context and methodology, describe my findings, and offer concluding reflections for pedagogical practice.

\section{INSTITUTIONAL CONTEXT AND METHODOLOGY}

This study was conducted at a mid-sized, four-year state college in the mid-Atlantic region of the United States, where majors are offered in one of seven different liberal arts or professional schools. Throughout the 2005 to 2008 academic years, the college implemented a WID curriculum, wherein two already-required courses in the major were redesigned to meet writing intensive guidelines. Thus throughout their college years, students take three WI courses: a first-year seminar in any discipline, a mid-level WI course in the sophomore or junior year, and a WI capstone course in the senior year. Table 1 above outlines the progression of courses taken by students majoring psychology and computer science.

The mid-level WI course for psychology is a research seminar involving a full empirical study conducted by students in small groups; they spend the entire semester writing all four sections (Introduction, Methods, Results, and Discussion) using APA format. Data is derived from an internal collection of empirical research studies conducted at the college by psychology faculty and undergraduate students. In the comparable mid-level WI course for computer science majors (on software engineering), students write papers in which they justify software application recommendations; here, the faculty member provides a template which uses many of the conventions of ACM pa- 
pers (Association for Computing Machinery), even though students are not conducting research.

Over the course of the 2012 spring semester, I conducted ten in-depth, text-based interviews with students enrolled in the mid-level and senior-level writing intensive courses in each of the two participating majors. ${ }^{4}$ Participants included three psychology seniors and three computer science seniors, as well as three psychology sophomores and one computer science sophomore. GPAs ranged from 3.324 to 3.913. All had taken a WI first year seminar on topics as diverse as the Beatles, Irish Cinema, and the Mind-Body Connection.

Among seniors, I intentionally limited requests to those doing independent research to ensure that they would be writing the discipline's major genre. All but one intended to go on to graduate school. The senior participants, in other words, have made it to Thaiss and Zawacki's stage three, possessing a "nuanced idea of the discipline" (2006, p. 110). They are, therefore, "excellent informants" (Morse, 2007, p. 231) for examining students' perceptions of the most helpful experiences in developing disciplinary writing expertise.

In January of that same semester, I also administered a survey to the sophomore and senior cohorts in each major. The response rate in computer science was $63 \%$ among seniors and $38 \%$ among sophomores, and in psychology it was $40 \%$ among seniors and $56 \%$ among sophomores.

Repositioned grounded theory (RGT) was used for its privileging of the language of participants, its acknowledgment of disciplinary assumptions ("sensitizing concepts"), and its iterative process of coding and analysis to derive interpretive categories (Charmaz 2002, 2006; Bryant and Charmaz 2010). The central disciplinary sensitizing concept informing my analysis is that disciplines are not "separate divisions of declarative knowledge," but rather, "ways of doing and thus ways of knowing and writing, modes of inquiry rather than static territories of knowledge" (Carter, 2007, p. 410). I was interested in discovering the activities that students perceive to have been most helpful in learning the scientific research article genre - a genre that is radically different from humanities-based writing preparation dominant in both high school and general education curricula.

Questions included open-ended inquiries about their development as writers over the course of their college career, perceived changes in their writing over time, awareness of different kinds of writing expected in different college courses, the most important lessons learned about how to write for courses in the major, experiences that have affected their development as a writer in the major, the most challenging aspect of writing in the major, and advice they would give to a first year student. In addition, text-based questions were used to have students re-examine their papers from mid- and senior-level WI courses. Students were asked to point to places where they felt most/least competent and confident about their writing ability, to passages which they learned to do in either the prerequisite or the mid-level WI course, to passages where they encountered a new challenge, and to passages which reflect their growth as a writer.

Results suggest that students gain the greatest rhetorical sophistication through a variety of forms of dialogue with more experienced members of their discourse community, through using genre templates early on in their curricular experience-especially when courses are intentionally sequenced_and through purposeful forms of reading and emulating scholarship in the field. 


\section{TALKING GENRE: EXTENDING STUDENTS' AUDIENCE AWARENESS TO THE DISCIPLINARY COMMUNITY}

The first significant category that emerged from the action codes was dialogue. The various kinds of "talk" that participants described all involve an informed professional who has discipline-specific expectations for successful writing. These scenarios included everything from thesis committee meetings in which faculty advisors provide oral feedback on drafts, to informal talk that, over time, has come to function as a form of mentoring. The passages underscore Prior's argument that textual production includes "talking and listening, reading and writing, thinking and feeling, observing and acting" (1998, p.137). These heterogeneous actions stress the holistic nature of "enculturation," with the social action achieved through the dialogues reflecting both an intellectual and affective component to genre learning.

Cecelia, a psychology senior, emphasized how in her meetings with her thesis advisor the dynamics involved a back-and-forth between equals, not a one-directional critique more reminiscent of a traditional teacher-student relationship. For example, when her advisor would point to something that she felt wasn't clear, she would prompt Cecelia to explain her rationale:

\section{If I said something like - I remember this too-I would say a word that like I thought had a lot of meaning but really didn't. So like, I don't know like, "Emotion regulation is suppressing or expressing emotion" and she would be like well "No it's not" and "if you think it is, why is it?"5}

This faculty member invites Cecilia to interact in a way that reflects respect for her knowledge, a process only feasible between co-members in the discipline. This relationship is illustrated again when Cecelia described a thesis committee meeting as one of the most important moments that influenced her development as a writer: "All of them were like 'Wow, this is a really good paper. It's a really interesting study, like I want to know what happens.' And that kind of validates that like oh, I'm doing something right." Her committee's validation of her as someone whose work they want to read has significant instructional ramifications.

Similar instances of this form of "talk" include Danny's discussion of what he called a breakthrough moment as a psychology writer. He referred not to specific papers or achievements, but to how faculty members actually speak to him. His desire for future dialogue is one of the primary motivations for his writing:

Well, I think that, and this is going to sound really nerdy, but I think that I, cause like I'm applying to graduate school, I just have such a respect for faculty... I really want to, in the way that I write and the way that I speak, I want to be respected by them. So when I talk to these people, I want to speak in the most sophisticated way because that's how they speak to me. And, you know I want them to ... I want to one day be, I don't know, their peers, does that make sense? [I suggested the term "colleague."] Yeah, their colleagues. So then I think that also sort of drives me to try to improve.

The desire to be treated as a colleague becomes a major motivation for Danny to be more effective in his writing. 
In a similar way, senior psychology major Michelle revealed how talk with faculty members has shaped her rhetorical development:
I knew that one of my audience members was a social psychology professor, so when I was writing I always had him in the back of my head, making sure that this was all accurate information, making sure he wouldn't stop and say, "no that's not accurate."

In this case, anticipating the conversation with her committee functioned to expand her knowledge of differences among sub-fields within the discipline.

Michelle also cited having a real audience beyond her professors as a key factor in her increasing effectiveness as a writer: "I'm going to be presenting this paper and hopefully one day get it published. So those people, if they don't know what I'm saying they're going to question it and that'll just kind of, um, limit the validity of it, especially in terms of how other people view it." Seeing her writing manifested in a social context (a conference) allows her to understand its validity as a function of her audience's understanding of her ideas, a strong motivating factor for her writing.

Michelle and her peers are describing a new motivation, a new socially constituted exigence for their writing. While in their general education classes they were primarily concerned with getting good grades or fulfilling requirements, they now consistently describe their concern with trying to meet the expectations of the discourse community. This change can be seen in how Justin, a senior computer science major, compared his writing for general education courses to his current research. He knows that one of his on-going challenges as a writer is trying to cover too much material, and his descriptions of earlier writing often sound like what Bean has called the "all about" or "data-dump" paper-characteristic of many novice college writers who are "overwhelmed with information and uncertain what to do with it" (1995, p. 23). In a course on the Vietnam War and Gender, for example, Justin explained that there was so much material to write about that he felt he'd be "penalized" if he "didn't include everything." The focus on a penalty indicates a primary concern with a grade.

His description of his senior-level disciplinary writing, however, has shifted to a more specific concern about meeting the expectations of readers in the computer science field. He still has to make decisions about what to include, but it is now framed in terms of what will gain him the acceptance and respect of community members. Here, for example, he talks about his realization of a very human, embodied audience for whom he needs to write his methodology section:
If I was trying to get into, say, just a minor conference or something, and I want to present this, and I wanna say here, "you know this is the problem and we wanted to make this scalable database system that people can use," I don't want to stand up there and talk about "then I did this, and then I used this tool."

If he were to do that, he feels he would likely get the following reaction: "Yeah we know that's how you do that, you're wasting our time." Aware of his readers' knowledge base, he knows that he cannot "re-explain" to them what they already know. Through these imagined harsh critics, Justin reminds himself that he cannot assume a general, nondisciplinary audience. 
Justin's genre learning is particularly instructive because he double majored in economics but has gained a level of mastery only in computer science writing. He explained how much of his growth has come from the way the computer science department has "cared for me, nurtured me, more than the other." In response to what advice he would give a first year student, he said "number one" was getting involved with faculty since they provide the guidance and support without which it is very difficult to succeed. Indeed, as Justin pointed out, although he is "more prone to be involved with a project in computer science" than in economics due to his primary career interest in that field, that difference in engagement with each department perpetuates the problem, "because I don't know how I would go about being involved with a project in economics, because it just seems like all theory to me." This lack of understanding, fueled in part by a lack of relationships, has had profound effects on Justin's genre learning. He acknowledged that he has a "good grasp on the computer science way of doing things," but when it comes to his economics thesis, he has "no idea what to do." In short, Justin doesn't know what "social action" would look like in economics; he doesn't know what its genres do.

\section{"LESS SUPERVISION AND MORE OWNERSHIP": MOVING FROM TEMPLATE TO DISCIPLINARITY}

Another experience identified by participants as supportive of their genre learning was using the template provided by the faculty member from the mid-level writing intensive course. Most sophomores were still at a stage where "filling in the blanks" was essential to being able to complete their papers. Although the technical language required in the sciences-so different from what's acceptable in the humanities-was also mentioned as a stumbling block, it was the structure of the genre itself that seemed quite alien, as psychology senior Michelle explained:

the first time I encountered writing like this was in [the Methods and Tools course], where even then I was like "what's a methods section, why would you put that into a formal paper?" It seems more of something that would be an appendix, or just like something separate, because it breaks the flow of the paper, cause, I thought, because it was another title, why would you, you know? That was the first time I ever encountered having to write like that, and at first it was very bizarre. Now when I look at every other class, I think "why aren't they like psych papers, it would make so much more sense."

By her final year, Michelle has internalized the scientific research article to such an extent that it now seems the norm to her. But her initial sense of confusion is not atypical. It harkens back to a question posed twenty years ago by Dias when he asked how his students can "close the gap between their writing and writing as it is modeled in the texts they continually meet in the disciplinary journals they read?" (1994, p. 194). Both this section and the next address how the students in my study answer that question.

The sophomore computer science majors who completed the survey all mentioned the "professional article style" of papers in their major as something significantly "different" from any writing they do elsewhere in college. As one student put it:

One of the more difficult aspects is the layout of computer science papers.

Unlike other papers, computer science papers follow an "outline." Each sec- 
tion is number (e.g. Section 1: Introduction, Section 1.1: More Information, etc.). This somewhat alien organization can be intimidating at first.

The computer science sophomore participant, Rick, indicated a comparable concern with structure when he identified his biggest challenged as simply understanding the difference between the abstract and the introduction. Senior computer science major, John, also mentioned that in the mid-level WI course "the whole format of [the paper] was new ... the abstract, introduction, like having all those." Following a model, however, proved crucial: "She gave us a document that had kind of what you should have in each section, which helped a lot, because there's a standard, and you kind of have to keep to the standard otherwise it's not good. So that definitely helped."

The following description of writing her first empirical research paper from psychology sophomore Nicole similarly reflects how important consulting a template is for genre learning (in the psychology curriculum, students receive an outline of the research article in the prerequisite methods course, usually taken a semester prior to the mid-level writing intensive course):

I think kind of the whole structure is what I learned from [the previous course]. And when I was writing it and ... hitting that road block ... is when I took out, um, one of the packets that he gave us, and looked at how he told us how to lay this out. So it was kind of just like: put an idea here and then give me some articles that support it. And put your next idea here and give me some articles that support it. And then after all that tell me how that leads up to what you're going to do.

Nicole is still following directions, in part because her professor realizes that at this stage, only rudimentary attention can be given to the complex rhetorical moves of the introduction, but she is gaining an introductory sense of the purpose of the structure.

Melissa, a psychology sophomore who had completed the mid-level writing intensive course by the time the interview was conducted, also referred to the helpfulness the template from the prerequisite course, despite realizing its limitations:
[The Methods and Tools course] was more about the format: what goes into what section. We did that one paper at the end but it wasn't very in- depth, it was more kind of like surface level, following a format. But I feel that looking back now, it was, we didn't, I didn't really understand a lot of it. We kind of, I mean we followed by example, but I feel like more of the writing, understanding and being able to replicate was in [the WI course].

Melissa's answer draws a distinction between surface copying or imitating and writing, an action that is far more complex because it involves a depth of understanding of the genre's disciplinarity. ${ }^{6}$

The explicit instructional component within the sequence of courses in this department's curriculum indicates a successful attempt by the faculty to articulate tacit genre knowledge in a way that is accessible to undergraduates early in the major. Nowhere is this more visible than in the survey responses to the prompt, "List some characteristics of a good paper written for a psychology course." Half of the sophomores identified adhering to APA guidelines as "the most difficult aspect of writing for your psychology courses," 
yet their ability to articulate the genre's structure and other requirements is fairly comprehensive. The following two answers are representative of many of the 36 responses:

A good paper has a short abstract that still summarizes the paper clearly with all of its main points, an introduction that gives a great background to your topic, a methods section that describes exactly what you did and how you did it, a results section that delivers your results, and a discussion section that describes what the results mean.

A good paper written in psychology has a clearly funneled introduction. The introduction and literature review are divided by topic, not by prior studies. The methods and research sections are written clearly, concisely, and in proper APA format. The discussion session is a backwards funnel, is not redundant, and offers insight to statistical results. A psychology paper should be informative, but easy to understand as well.

On the one hand, these descriptions would likely please any faculty member teaching the mid-level WI course. On the other hand, the ability to describe does not necessarily translate into performance. Perhaps more importantly, these and other responses are more like the checklists one might see on an assignment sheet. They don't necessarily reflect an understanding of the disciplinarity of the genre: its rhetorical complexity, its audience, or its purpose-beyond that of earning a grade.

In contrast, nearly half of the senior respondents say that a good paper must be wellinformed and reflect the author's knowledge of the material, that it must "successfully utiliz[e] the research of others to support your own investigation," and that it should present the "theoretical background and basis for topic/study." These concerns are not focused on structure, but rather, on function in relation to an audience-in other words, with the socio-rhetorical actions that genres perform.

Senior interview participants were likewise able to talk with ease about their understanding that genre is not a format "that must be slavishly followed," but a set of "rhetorical choices" that must be carefully negotiated throughout the text (Bazerman, 2009a, 504). Danny, for example, noted that although the other sections of the research article follow "strict guidelines," the introduction "has the most leeway in how you construct it" because "the challenging thing is to talk about why your research will be different and why it will be important." To do this, he explained that

you have to find things that, things in existing research that are not talked about enough, not talked about at all, that are confusing or contradictory. It translates into the writing because then how do you piece that together coherently, so that your audience understands what you're talking about, and they can follow your logic in your mind, how you connected everything.

Danny is concerned with the logic that his introduction has to perform: it must contextualize and justify the questions at the heart of his study, and it must do so in a way that leads the reader to see the gap, absence, or contradiction being addressed. To use the terminology developed by Swales in his linguistic analysis of the scientific research article, Danny sees that his text must establish a territory, establish a niche, and then occupy that niche (1990, p. 141). 
Several seniors highlighted the difference between knowing the structure of the genre and actually "doing" it, but the most striking account comes from Cecelia. Her senior thesis deals with three variables, two of which are well-known and accepted concepts. Her contribution is positing the third concept's relationship with the other two, a task made harder because she can find only one paper on the concept, and it's from a different subfield in psychology: "So I had to kinda turn something that was largely psycholinguistic and make it into like a clinical construct." Highly aware of her role in relation to other discourse community members, Cecelia admitted that developing a rationale for a meditational hypothesis was "close to impossible" because "not only was it a mediational hypothesis but it was something with mitigation which just doesn't exist in the literature. All this makes sense in my head but if no one can see that it's regulation then there's really no point to it." Cecelia's challenge as described here is not merely the difficulty of working with multiple causal variables. Rhetorically, she is aware that she must set up her hypotheses using the terms that the discourse community will recognize. As a student so highly sensitive to the rhetorical demands of the introduction, Cecelia illustrates how her genre performance has moved well beyond following a template.

\section{READING AND EMULATING}

During her interview, sophomore psychology major Nicole described several strategies she used to address the challenges she was facing in her research seminar paper (the mid-level WI course). To help her more effectively transition "between the different articles in a way that made it all flow and lead up to my research," she said that she frequently went back to her notes and handouts from the previous class. Like others, she relied on the template for guidance. But in addition, Nicole mentioned another activity that was cited universally by the seniors as one of the most important ways they learned to write: "just all the reading that I've had to do from my different psych classes, like article reading, without even really realizing it kind of showed me what that writing was supposed to do." She doesn't say that reading the scholarship showed her what the writing was supposed to look like, but instead, what it was supposed to do.

All six seniors identify reading as either the top piece of advice they would give to a first year student ("Be a good reader, number one. Read everything, especially scientific articles. If you can't understand one, you can't really be expected to write your own"), or as the thing that contributed the most to their own development as a writer ("The most influential way that I learned how to write is reading other psych articles and following by example"). Participants spoke about the importance of reading most often in the context of learning how to emulate, a process involving an awareness of how articles are structured and how authors use the structure effectively to achieve their desired ends-a process similar to what Greene calls "mining the text" or reading with a sense of authorship (1992, pp. 156-61).

Computer science senior, John, for example, noted that the abstract in his current paper is "more thoughtful" than the abstract in one of his papers from the mid-level course thanks to the intentional two-step method he used: "I looked at people's abstracts in the ACM library" and then compared them to what he'd done in his own previous papers. John's is an active process that goes beyond rote imitation. In fact, John referred to active reading as a "turning point" in his sense of himself as a writer. The first time he wrote a full research article was the fall prior to the interview, in a Mentored Research course. It 
was going to be submitted for a conference, and therefore would be peer reviewed. That semester, he explained,

I had to do mostly just reading to prepare for that. So by the time I had read 20-30 papers, I had gotten an idea of like what has been published and what it takes to be published. I was a lot more critical of myself then than I would have been if I didn't read all those papers because I didn't know what it took to be published. That was probably the turning point.

Reading enabled an active, self-evaluative process of applying the standards and norms of the field to his own writing.

John also remarked that he wished he'd been exposed to published scholarship earlier than he was: "And I wish we did have more reading before that. I think it would have helped us understand what we have to emulate." He is not alone. Danny said that although "it's unpopular" to assign 20-page research articles to "college freshmen," even just the exposure helps: "It gets you accustomed to the style, it gets you accustomed to how people speak, how they write." His first "foray" into reading published scholarship enabled him to "see how things were written" so that he "could emulate that or begin to incorporate that into mine." Finally, Justin also expresses the need for earlier exposure to scholarship, even calling this a "short-coming of the department" that they "haven't really been pushing students to analyze" academic papers. He sees now that his growth "has come through emulating, just emulating what I see."

This emphasis on reading was echoed in the survey in ways that provide instructive insights about the sequence of courses in this WID curriculum. Students were asked, "What experiences in your undergraduate career have best prepared you for the writing you've done so far as a psychology/computer science major? (Check all that apply)." Choices included the first year seminar, a first year composition class, the mid-level WI class, other courses in the major, general education classes, a specific paper you wrote, working with a particular professor, a faculty member's feedback on papers, the experience of reading published scholarship, and "Other." Students were then asked to rank their selections.

Among computer science sophomores, $86 \%$ of respondents selected the mid-level WI course, with $50 \%$ of those indicating this as their top choice. The remaining top rankings were split (17\% each) among reading published scholarship, working with a particular professor, and other (high school writing). Among seniors, the mid-level WI course and reading published scholarship were the top selections (60\% each); of these, $44 \%$ of respondents ranked the mid-level WI course as their top choice, and $22 \%$ ranked reading published scholarship at the top. That both sophomores and seniors valued the mid-level WI class so highly might well be a function of the fact that there are very few writing assignments in other courses in the curriculum (aside from writing code and commentary on the code).

Among psychology majors, the trends are similar, with two important differences. First, the sophomores identified the prerequisite courses (69\%) more frequently than the mid-level WI course (56\%) as that which best prepared them for their writing in the major. Second, the prerequisite course in which students first received the template for the scientific research article was identified as the first choice by $28 \%$ of respondents, and the mid-level WI course was ranked as the top choice among $26 \%$. The selections 
by senior psychology majors echo those made by the computer science students, with $81 \%$ of respondents selecting the mid-level WI course and reading published scholarship. Of these, 52\% ranked the mid-level WI course first, and 15\% ranked reading published scholarship as first.

The survey results in conjunction with the interviews suggest that the specific curriculum design for these two departments in this WID program worked in tandem with pedagogical practices (especially in psychology) that emphasized reading scholarly articles.

\section{CONCLUSION}

Concern with student writing in higher education is obviously not limited to the United States. Lillis and Turner articulated the growing sense of the "problem" of student writing in higher education in the UK fifteen years ago (2001). Their specific focus was on the difficulties created when students are "welcomed into the academy by the rhetoric of widening participation, but at the same time denied an adequate participation by takenfor-granted assumptions about academic conventions" (p. 66). Once again, assumptions about language are at the center: when students can replicate the "institutionally embedded socio-rhetorical norms of scientific rationality, language remains invisible” (p. 65). Lillis and Tunrer's call for putting language (and not student "deficits") at the center of pedagogical reforms (see also Haggis, 2006), is another reason for paying close attention to how students experience their own academic literacy development.

The in-depth interviews in my study indicated that what was most valued by students is having "strong and growing access to disciplinary discourses, practices, and relationships” (Prior, 1998, p. 133). Their dialogue with faculty members helped foster relationships that provided a strong sense of disciplinary understanding and identity. These relationships both stemmed from and resulted in additional faculty-student projects, including summer research grants, conference proposals and presentations, and other paraprofessional experiences such as online technology forums and institutional research pools. Participants' disciplinary genre learning and their emerging sense of membership within the discipline echo the findings of other WID studies as summarized by Russell, particularly Jolliffe and Brier's study of political science and nursing students, where "acquisition, use, and awareness" of the discipline's knowledge was directly related to the extent of students' self-image as "soon-to-be-professionals" and their active involvement in professional work (2001, p. 10).

More direct instructional practices were also essential in supporting their disciplinary writing. The use of templates, while not sufficient in and of itself, provided a foundation for later "deep participation" so necessary for disciplinary enculturation (Prior, 1998, p. 103). By the time they were seniors, students in both majors found "texts reasonably transparent and appropriable" (Prior, 1998, p. 133). The reading and emulating promoted by the faculty members in their departments is an example of "modeling," a pedagogical practice identified by multiple other studies as essential for genre learning in WID (Russell, 2001, p. 17).

The reading activities noted by these participants are similar to practices developed in a comprehensive pedagogical study in chemistry, where a "read-analyze-write approach to genre-based instruction" was used with undergraduates at Northern Arizona University (Stoller and Robinson, 2012, p. 46). Their method of explicit identification of the 
rhetorical moves used in chemistry articles has since been developed into a textbook and companion website (Stoller and Robinson, 2012).

My study, although limited in scope, nevertheless offers support for other calls that stress the importance of "teaching writing" in the disciplines. As Carter has argued, such movements do not ask faculty in the disciplines to become "writing teachers," but rather, to "see that their responsibility for teaching the ways of knowing and doing in their disciplines also extends to writing, which is not separate from but essential to their disciplines" (2007, p. 408). Such commitments can work in concert with WAC and newer composition initiatives such as "Writing about Writing" (Downs and Wardle 2007; Wardle 2009) to create curricula where writing can be experienced as a purposeful activity "within a rich, multi-dimensional communicative environment” (Bazerman and Prior, 2005, p. 164).

Equally important is the question not examined in my study: what does it look like when students do not learn genre, or do not make it to Thaiss and Zawacki's stage three of undergraduate disciplinary writing development? What is their learning experience of genre like when they remain mired in navigating what they see only as the expectations of individual faculty members? Future studies in this area, again from the student perspective, would shed important light on why some things are hard for students to learn, and thereby enhance our understanding not only of the learning process more broadly, but also of methodologies for the Scholarship of Teaching and Learning.

Mary Goldschmidt is the Faculty Development Specialist at the Center for Teaching and Learning Excellence at the University of Scranton, Pennsylvania (USA).

\section{NOTES}

1. My research was made possible in part by the 2011-2013 Elon University Research Seminar on Critical Transitions: Writing and the Question of Transfer. Special thanks to Jessie Moore, Associate Director of the Center for Engaged Learning at Elon University and associate professor of Professional Writing \& Rhetoric in the Department of English, for her feedback on earlier versions of this manuscript.

2. The field of Composition and Rhetoric in the U.S. has raised serious questions about the genres that dominate traditional curricular models, whether that be through broad calls to do away with first year writing courses altogether (Connors 1995; Petraglia1995; Smits 2004), activity system theory and a critique of first-year composition's ability to teach disciplinary genres out of context (Russell 1995; Bawarshi 2003; Downs \& Wardle 2007; Wardle 2009), or empirical studies showing that for a variety of reasons transfer from one genre to another either seldom happens or students don't expect that it will (Beaufort 2007; Nelms \& Dively 2007; Bergman \& Zepernick 2007; Wardle 2007; Clarke \& Hernandez 2001; Driscoll 2011).

3. The scholarship on genre learning involves decades-long, international debates about the efficacy of explicit instruction in teaching genre, with some studies contending that explicit teaching is neither necessary nor helpful, and others providing evidence that explicit instruction can be effective (for authoritative summaries, see Freedman 1994, and Bawarshi \& Reiff, 2010, pp. 110-126). This curriculum, where there was "explicit" teaching of the scientific research article genre, thus offered a window into these dynamics. 
4. This study was IRB approved in 2011. All student names have been changed.

5. I chose a naturalized transcription method, without editing repetitions or the frequent use of "like" etc., in order to capture both the conversational nature of the interviews and students' often difficult articulation of their understanding of their own literacy development.

6. If Melissa means "replicate" in its scientific sense, as I believe she does, then her comment suggests the mid-level WI course can entail a step beyond simply copying a template. Instead, there is the potential for an experience of replicating an experimental study to test for reliability, a skill which requires an independent ability to conduct research.

\section{REFERENCES}

Artemeva, N. (2008). Toward a unified theory of genre learning. Journal of Business and Technical Communication, 22, 160-185.

Bawarshi, A. (2003). Genre and the invention of the writer. Logan, UT: Utah State University Press.

Bawarshi, A and Reiff M. (2010). Genre: An introduction to history, theory, research and pedagogy. West Lafayette Indiana: The WAC Clearninghouse and Parlor Press. Retrieved from http://wac.colostate.edu/books/bawarshi_reiff/

Bazerman, C. (2009a). The problem of writing knowledge. In S. Miller (Ed). The norton book of composition studies (pp. 502-14). New York: W.W. Norton and Company.

Bazerman, C. (2009b). Genre and cognitive development: beyond writing to learn. In C.

Bazerman, A. Bonini, and D. Figueiredo (Eds.), Genre in a changing world (pp. 279-94). Fort Collins, Colorado: The WAC Clearinghouse and Parlor Press. Retrieved from http://wac .colostate.edu/books/genre.

Bazerman, C. and Prior P. (2005). Participating in emergent socio-literate worlds: Genre, disciplinarity, interdisciplinarity. In R. Beach, J. Green, M. Kamil, and T. Shanahan (Eds.), Multidisciplinary perspectives on literacy research ( $2^{\text {nd }}$ ed.), (pp. 133-78). Cresskill, NJ: Hampton Press.

Bazerman, C., et al. (2005). Reference guide to writing across the curriculum. West Lafayette Indiana: The WAC Clearninghouse and Parlor Press. Retrieved from http://wac.colostate .edu/books/bazerman_wac/

Bean, J. (1995). Engaging ideas ( $1^{\text {st }}$ ed). San Francisco, CA: Jossey-Bass Publishers.

Beaufort, A. (2007). College writing and beyond: A new framework for university writing instruction. Logan, UT: Utah University Press.

Beaufort, A. and Williams, J. (2005). Writing history: Informed or not by genre theory. In A. Herrington and C. Moran (Eds.). Genre across the curriculum (pp. 44-64). Logan, Utah: Utah State University Press.

Bergman, L, and J. Zepernick. (2007). Disciplinarity and transference: students' perceptions of learning to write. WPA: Writing Program Administration 31(1/2), 124-149.

Bryant, A. and Charmaz, K.. (2010). Grounded theory in historical perspective: An epistemological account. In A. Bryant and K. Charmaz (Eds). The sage handbook of grounded theory, (pp. 31-57). Los Angeles: Sage.

Carter, M. (2007). Ways of knowing, doing and writing in the disciplines. College Composition and Communication 58(3), 385-418. 
Charmaz, K. (2002). Qualitative interviewing and grounded theory analysis. In J. Gubrium and J. Holstein (Eds.). Handbook of interview research: Context and method, (pp. 675-94). London: Sage.

Charmaz, K. (2006). Constructing grounded theory: A practical guide through qualitative analysis. Thousand Oaks, CA: Sage.

Clark, I. and A. Hernandez. (2011). Genre awareness, academic argument, and transferability. The WAC Journal, 22. Retrieved from http://wac.colostate.edu/journal/vol22/clark.pdf

Connors, R. (1995). The new abolitionism: Toward a historical background. In J. Petraglia (Ed.) Reconceiving writing, rethinking writing instruction (pp. 3-26). Mahwah, NJ: Lawrence Earlbaum.

Cooper, M. (1989). The ecology of writing. In M. Cooper and M. Holzman (Eds.) Writing as social action (pp. 1-13). Portsmouth, NH: Boynton/Cook.

Dias, P. (1994). Initiative students into genres of discipline-based reading and writing. In A. Freedman and P. Medway (Eds.). Learning and teaching genre (pp. 193-206). Portsmouth, $\mathrm{NH}$ : Boyton/Cook.

Downs, D. and E. Wardle. (2007). Teaching about writing, righting misconceptions: (re)envisioning 'first-year composition' as 'introduction to writing studies." College Composition and Communication 58(4), 552-584.

Driscoll, D. (2011). Connected, disconnect, or uncertain: student attitudes about future writing contexts and perceptions of transfer from first year writing to the disciplines." Across the Disciplines 8.2. Retrieved from http://wac.colostate.edu/atd/articles/driscoll2011 /index.cfm.

Elton, L. (2010). Academic writing and tacit knowledge. Teaching in Higher Education 15(2), 151-60.

Freedman, A. (1994). "Do as I say": the relationship between teaching and learning new genres. In A. Freedman and P. Medway (Eds). Genre and the new rhetoric (pp. 191-210). Bristol, PA: Taylor and Francis, Inc.

Greene, S. (1992) Mining texts in reading to write. Journal of Advanced Composition 12, 151-70.

Haggis, T. (2006). Pedagogies for diversity: Retaining critical challenge amidst fears of 'dumbing down.' Studies in Higher Education 31(5), 521-35.

Hutchings, P. (2000). Opening lines: Approaches to the scholarship of teaching and learning. Menlo Park, CA: The Carnegie Foundation for the Advancement of Learning. Retrieved from http://www.carnegiefoundation.org/elibrary/approaching-scholarship-teaching -and-learning

Hunt, R. (1994). Traffic in genres, in classrooms and out. In A. Freedman and P. Medway (Eds.). Genre and the new rhetoric (pp. 211-30). Bristol, PA: Taylor and Francis, Inc.

Kaufer, D. and Young, R. (1993). Writing in the content areas. In L. Odell (Ed.). Theory and practice in the teaching of writing: Rethinking the disciplines (pp. 71-104). Carbondale, IL: Southern Illinois University Press.

Lillis, T. and Turner, J. (2001). Student writing in higher education: contemporary confusion, traditional concerns. Teaching in Higher Education 6(1), 57-68.

Miller, C. (1984). Genre as social action. Quarterly Journal of Speech 70, 151-67. 
Morse, J. (2007). Sampling in grounded theory." In A. Bryant and K. Charmaz (Eds). The sage handbook of grounded theory, (pp. 229-44). Los Angeles: Sage.

Nelms, G. and R. Leathers Dively. (2007). Perceived roadblocks to transferring knowledge from first-year composition to writing-intensive major courses: a pilot study. WPA: Writing Program Administration, 31(1/2), 214-45.

Petraglia, J. (1995). Writing as an unnatural act. In J. Petraglia (Ed.) Reconceiving writing, rethinking writing instruction (pp. 79-100). Mahwah, NJ: Lawrence Earlbaum.

Prior, P. 1998. Writing/Disciplinarity: A sociohistoric account of literate activity in the academy. Mahwah, NJ: Lawrence Erlbaum Associates.

Russell, D. (1995). Activity theory and its implications for writing instruction." In J. Petraglia (Ed.) Reconceiving writing, rethinking writing instruction (pp. 51-77). Mahwah, NJ: Lawrence Earlbaum.

Russell, D. (2001). Where do the naturalistic studies of WAC/WID point? A research review. In S. McLeod, et al. (Eds) WAC for the new millenium: Strategies for continuing writingacross-the-curriculum programs (pp. 259-88). Urbana, IL: NCTE. Retrieved from http://wac .colostate.edu/books/millennium/chapter11.pdf

Russell, D. (2002). Writing in the academic disciplines: A curricular history $\left(2^{\text {nd }}\right.$ ed.) Carbondale, IL: Southern Illinois University Press.

Smits, D. W. (2004). The end of composition studies. Carbondale, IL: Southern Illinois University Press.

Stoller, F. and Robinson, M. (2012). Chemistry journal articles: An interdisciplinary approach to move analysis with pedagogical aims. English for Specific Purposes 32, 45-57.

Swales, J. (1990). Genre analysis: English in academic and research settings. Cambridge: Cambridge University Press.

Thaiss, C. and T Meyers Zawacki. (2006). Engaged writers and dynamic disciplines: Research on the academic writing life. Portsmouth, $\mathrm{NH}$ : Boynton/Cook.

Wardle, E. (2007). Understanding 'transfer' from fyc: preliminary results of a longitudinal study.

WPA: Writing Program Administration, 31(1/2), 65-85.

Wardle, E. (2009), "Mutt genres" and the goal of fyc: can we help students write the genres of the university? College Composition and Communication, 60:4, 765-89. 